\title{
New records of two little known coleopteroid species of Rhyparochromidae Amyot \& Serville, 1843 (Heteroptera: Lygaeoidea) in Patagonia
}

\author{
Nuevos registros de dos especies con coleoptería \\ poco conocidas de Rhyparochromidae Amyot \& Serville, 1843 \\ (Heteroptera: Lygaeoidea) en Patagonia
}

Eduardo I. Faúndez ${ }^{1,2}$

\begin{abstract}
New records are provided for the Rhyparochromid bugs Stictolethaeus inerme (Berg, 1883) and Astemmoplitus nitidus (Blanchard, 1852). S. inerme is recorded for the first time in the Neuquén Province in Argentina; whereas A. nitidus is reported for the first time in Los Lagos Region in Chile. Futaleufú becomes the southernmost record known for this species. The relationship between A. nitidus and A. gayi (Spinola, 1852) is commented and clarified.
\end{abstract}

\section{Key words:}

Hemiptera, Lethaeini, Udeocorini, Los Lagos, Neuquén, new records, synonymy.

\section{Resumen}

Se entregan nuevos registros para los Riparocrómidos Stictolethaeus inerme (Berg, 1883) y Astemmoplitus nitidus (Blanchard, 1852). Se registra a $S$. inerme por primera vez para la provincia de Neuquén, Argentina; mientras que $A$. nitidus se registra por primera vez para la Región de Los Lagos, Chile. Futaleufú se convierte en la localidad más meridional conocida para ésta especie. En adición la relación entre $A$. nitidus y A. gayi (Spinola, 1852) es comentada y clarificada.

\section{Palabras clave:}

Hemiptera, Lethaeini, Udeocorini, Los Lagos, Neuquén, nuevos registros, sinonimia.

\section{INTRODUCTION}

Rhyparochromidae Amyot \& Serville, 1843 is a family of small heteropterans, with white, black, brown and opaque coloration. This group is one of the most diversified within Lygaeoidea (Schuh \& Slater, 1995); comprising 1850 species classified in 372 genera (Henry, 2009). This taxon was formerly treated as a subfamily of Lygaeidae, until Henry (1997), who gave it a family status. Actually the group remains classified as a family within the Lygaoidea sensu stricto (Faúndez, 2014). Within the Rhyparochromidae, several species are known by having coleopteroid hemelytra (e.g. with reduced or absent membrane and corium fused with the clavus). The purpose of this contribution is to give new records of two coleopteroid Rhyparochromids in Patagonia.

\section{MATERIALS AND METHODS}

In classification we follow Slater (1964) and Henry (1997). Photos were taken with a high resolution digital camera adapted to a stereoscopic microscope. All examined material is deposited in the Heteroptera Reference Collection of the Centro de Estudios en Biodiversidad CEBCh.

1 Entomology Department, School of Natural Resource Sciences, North Dakota State University, Fargo, ND, USA. $\Sigma$ ed.faundez@gmail.com.

2 Departamento de Zoología Médica, Centro de Estudios en Biodiversidad (CEBCh), Magallanes 1979, Osorno, Chile. 


\section{RESULTS}

Rhyparochromidae Amyot \& Serville, 1843

Rhyparochrominae Amyot \& Serville, 1843

Lethaeini Stål, 1872

Stictolethaeus inerme (Berg, 1883) (Fig. 1)

= Stictolethaeus slateri O'Donnell, 1991 (syn. by Dellapé \& Coscarón, 2004).

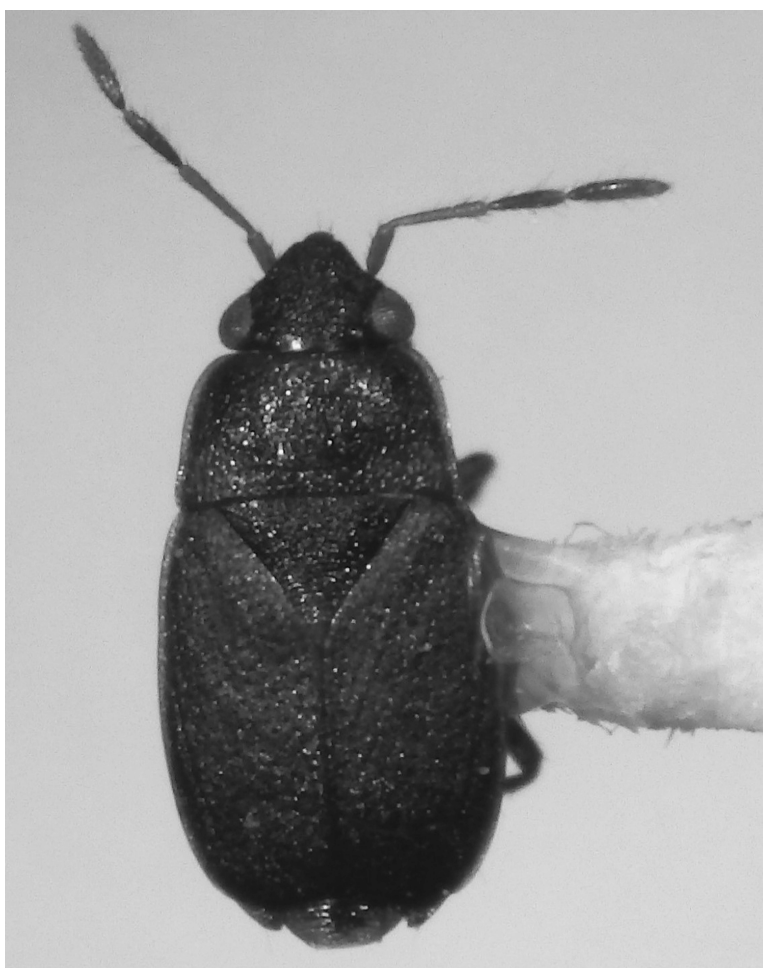

Fig. 1. Stictolethaeus inerme, habitus.

Material examined: ARGENTINA: Neuquén Province, $16 \mathrm{~km}$ NE of San Martín de los Andes 4007'S-7106'W 700m s.n.m. 13-I-1988, Ashworth, Fuglseth \& Maliscke leg. $10^{\prime \prime}$ (micropterous), Patagonian steppe Umbelliferae/Compositae/ Poaceae, pitfall trap.

Remarks. This species is known from Argentina and Uruguay. In Argentina it has been recorded from Buenos Aires, Catamarca, Córdoba, Chubut, Entre Ríos, Mendoza, Santa Fé (Dellapé et al. 2015). Here we provided the first record of this species in the Neuquén Province, extending its distribution to the East in the southern edge of its distribution.

\section{Udeocorini Sweet, 1967}

Astemmoplitus nitidus (Blanchard, 1852) (Fig. 2)

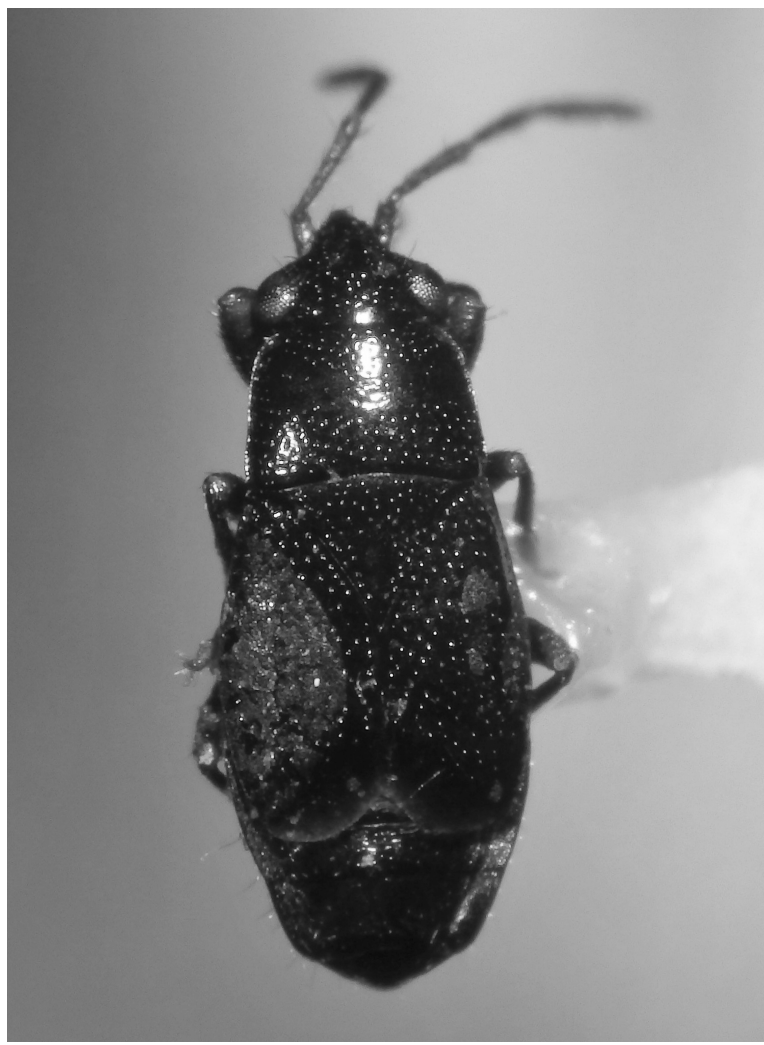

Fig. 2. Astemmoplitus nitidus, habitus.

Material examined: CHILE: Los Lagos Region, $5 \mathrm{~km} \mathrm{~W}$ of Ensenada, Llanquihue, 18IX-1977, 19, Ashworth, Hoganson \& Mooers leg. Los Lagos Region, Futaleufú, 26/29-I-2015, $10^{\top 1} 1$ A. Luer leg.

Remarks. This species is known in Chile only from the type localities "Concepción y Araucanía" given by Blanchard (1852). Besides of that, it has only been cited in Río Negro, Argentina by Dellapé et al. (2010). The records here provided extend the presence of this species to Palena Province in Chile. Prado (2008) list this species as a junior synonym of Astemmoplitus gayi (Spinola, 1852) without justification. In the case of a synonymy, A. nitidus has precedence (i.e. page 150) over A. 
gayi (i.e. page 157) in the same text (Spinola \& Blanchard, 1852). However, A. gayi is distributed in the North-Central part of the country (with Coquimbo Region as type locality); whereas $A$. nitidus ranges from Bío Bío to Los Lagos regions. Furthermore, the type of $A$. gayi is lost and there is not enough material available to further study the synonymy of both species. Therefore, we prefer to treat them as different taxa until more material is available for study.

\section{DISCUSSION AND CONCLUSIONS}

The scarce amount of records of these species seems to be related to lack of collecting. The case of $S$. inerme is interesting because it reach the Andes limit, however it has been never found in Chile. Therefore, further prospection may extend its presence to Chile; as it has been occurring recently with many heteropterans recorded for the first in the south of Chile or Argentina respectively (Faúndez \& Rider, 2016). Moreover, the new locality data of $A$. nitidus fill the distributional gap between Southern Chile and Argentina; thus showing a classical Andean pattern. Futaleufú becomes the southernmost record known for this species.

\section{ACKNOWLEDGEMENTS}

I thank Allan Ashworth and Alfredo Luer for providing the material used on this work.

\section{LITERATURE CITED}

Amyot, C. J. B., \& Serville, J. G. A. (1843). Histoire naturelle des insectes. Hémiptères. Paris: Fain et Thunot.

Berg, C. (1883). Addenda et emedanda ad Hemiptera Argentina. Anales de la Sociedad Científica Argentina, 15(5), 193217.

Dellapé, P. M., \& Coscarón, M. C. (2004). New combination and new synonymy in the tribes Megalonotini and Lethaeini (Heteroptera:
Rhyparochromidae). Revista de la Sociedad Entomológica Argentina, 63, 17-18.

Dellapé, P. M., Carpintero, D. L., \& Melo, M. C. (2010). New records of Dipsocoromorpha, Cimicomorpha and Pentatomomorpha (Hemiptera: Heteroptera) from Argentina, Zootaxa, 2436, 57-64.

Dellapé, P. M., Melo, M. C., \& O’Donnell, J. E. (2015). Biodiversity and distribution of lethaeine seed bugs (Heteroptera, Rhyparochromidae, Lethaeini) from Argentina. Zoological Studies, 54, 34.

Faúndez, E. I. (2014). The Lygaeoidea sensu lato of Magallanes Region: Checklist and identification key to the species. Anales del Instituto de la Patagonia, 42(2), 59-63.

Faúndez, E. I., \& Rider, D. A. (2016). Notas sobre el complejo de Acledra (Acledra) albocostata (Spinola, 1852) (Hemiptera: Heteroptera: Pentatomidae: Pentatominae). Arquivos Entomolóxicos, 15, 383-389.

Henry, T. J. (1997). Phylogenetic analysis of family groups within the infraorder Pentatomomorpha(Hemiptera: Heteroptera), with emphasis on the Lygaeoidea. Annals of the Entomological Society of America, 90(3), 275-301.

Henry, T. J. (2009). Biodiversity of Heteroptera, In R. G. Foottit \& P. H. Adler (Eds.), Insect Biodiversity: Science and Society (pp. 223263). Oxford: Wiley-Blackwell.

Prado, E. (2008). Conocimiento actual de Hemiptera-Heteroptera de Chile con lista de especies. Boletín del Museo Nacional de Historia Natural, 57, 31-75.

Schuh, R. T., \& Slater, J. A. (1995). True bugs of the World (Hemiptera: Heteroptera): Classification and Natural History. New York, Ithaca: Cornell University Press

Slater, J. A. (1964). A Catalogue of the Lygaeidae of the World. University of Connecticut, Storrs, Connecticut, 2 vols. 1668 pp.

Spinola, M., \& Blanchard, E. (1852). Hemípteros. In C. Gay (Ed.), Historia física y política de Chile. Zoología, Vol 7 (pp. 113-320). Paris. 
